\title{
Institutional Determinants of Tax Morale in Pakistan
}

Ghulam Rasool Madni, Mohammad Aslam Chaudhary and Nawaz Ahmad ${ }^{1}$

\begin{abstract}
Deterrence policy is a prevalent strategy in developing countries to collect tax revenues, but this approach is problematic due to inconsistent evidence. Tax morale is emerging as one of the most influential variables affecting the level of compliance in most countries. Given the extremely low tax to GDP ratio in Pakistan, the foundational intent of this study is to examine the impact of formal and informal institutions affecting the level of tax morale and to fill the space by considering tax morale as endogenous variable by acquiring the data from the World Values Survey for the wave of 2010-2014. Weighted ordered probit model is applied, the estimated results demonstrate that confidence in parliament, confidence in civil services, confidence in government, religiosity, marital status and person's age play significant roles in building higher tax morale in the country. It has also been observed that Pakistani women have higher level of tax morale as compared to men. Married people turn out to have higher tax morale as compared to singles and financial satisfaction has also significant positive impact for tax morale while the impact of education was not found significant. From policy perspectives, the improvement of institutional quality has dire need to improve the level of tax morale.
\end{abstract}

Keywords: Tax Morale, Institutions, Weighted Ordered Probit Model

\section{JEL Classification: $\mathrm{H} 260$}

\section{Introduction}

Taxes are an important source of public revenues in the fiscal system of a country because they help to combat poverty and finance the provision of social and physical infrastructure. Sustainable growth is based upon provision of public services like infrastructure, educational and health facilities etc. However, collecting taxes is often quite challenging in many countries. These challenges comprise of outsized informal sector, a small tax base, ineffective governance and administrative capability, poverty and tax evasion by elite class.

\footnotetext{
${ }^{1}$ The authors are assistant professor, Professor and Associate Professor respectively at Department of Economics, The University of Lahore. For correspondence: ghulam.rasool@econ.uol.edu.pk
} 
The findings of Allingham and Sandmo (1972) suggests the use of deterrence policy for tax payers regarding implementation of taxation rules and proposes penalties in cases of breaches of tax laws. But experimental and empirical evidences indicate that deterrence policy is not much effective to overcome tax evasion in an economy as the coverage of deterrence policy is very small in numerous economies as described in Torgler (2002).

Why few individuals are tax payers while others are not? This debate got much attention in the taxation literature since last many decades and there are many theories explaining the above-mentioned question. Rational choice theories explain that if anticipated penalties or probability of being caught are lower as compared to the avoidance of taxes, then gains will be higher. In this case, people have more attraction to avoid the taxes and noncompliance behavior will prevail. Hanousek and Palda (2004) argued that excellence of public services plays a crucial role in the tax compliance. When public trusts that taxes will be utilized for public and social services, and it will not end up into the pouches of revenue authorities and politicians, then they are expected to pay taxes. When corruption on a large scale prevails and the legal system is weak, the level of tax compliance will be reduced. If people have trust in honesty of officials, it will increase their trust in the government.

Torgler (2007) pointed out, "Taxes can be seen as a pride paid for government's positive actions. If the government tries to generate trust with wellfunctioning institutions, co-operation can be initiated or increased, when taxpayers are satisfied with the way they are treated, the cooperation is enhanced. If the outcome received from the government is judged to be fair in relation to the taxes paid, no distress arises."

The deterrence policy may be replaced by or supplemented with emphasizing the tax morale of people to collect the revenues (Dubin, 2007). Tax morale is self-motivation or eagerness of individuals to pay taxes. It is an important factor for resource mobilization and responsibility to pay taxes and shows patriotism and devotion to the nation. It does not gauge the behavior of individuals, but it determines the attitude of tax payers. It can be perceived a moral obligation of tax payers and their conviction for development of community by paying taxes (Torgler and Schneider, 2007).

Pakistan is among one of the world's lowest tax to GDP ratio countries and facing significant challenges in realization of its potential tax revenues. The tax to GDP ratio has increased to 12.4 percent over the past three years but is still not competing 
with other developing economies of the region. This ratio remained stagnant since long as shown in the Table (1).

Table: 1 Revenues as Percentage of GDP in Pakistan

\begin{tabular}{llllll}
\hline Variables/Years & $\mathbf{1 9 7 0}$ 's & $\mathbf{1 9 8 0}$ 's & $\mathbf{1 9 9 0}$ 's & $\mathbf{2 0 0 0 ' s}$ & $\mathbf{2 0 1 1 - 1 5}$ \\
\hline Tax Revenues & 11.4 & 13.2 & 13.0 & 10.9 & 10.2 \\
Nontax Revenue & 2.3 & 3.6 & 4.2 & 4.0 & 3.3 \\
Total Revenues & 13.7 & 16.8 & 17.2 & 16.4 & 13.5 \\
\hline
\end{tabular}

Source: The World Bank and Pakistan Economic Survey (Various Issues).

Pakistan is confronting the deep financial crisis that cannot be easily solved. Pakistan collected very low tax revenues throughout the 1970s. In 1980s, tax to GDP ratio was $13.2 \%$ which was further decreased to $13.0 \%$ at the end of the $90 \mathrm{~s}$. This declining trend continued till the first decade of 2000s and tax to GDP ratio fell to $10.9 \%$, getting the lowest position in the region. This ratio remained at $9.8 \%$ in 2012-13 against $10.2 \%$ in 2011-12 while slightly increased to $10.2 \%$ and $11.5 \%$ in 2013-14 and 2014-15, respectively. Despite many initiatives and schemes like Universal Self-Assessment Scheme (USAS), establishment of regional tax offices, introduction of single National Tax Number (NTN), Sales Tax Risk Evaluation and Management System (STREAMS), Sales Tax Automated Refund Repository System (STARRS) etc. ${ }^{2}$, no significant change could be brought about in revenue collection. These tax revenues are not enough to combat poverty, provision of education, health and other public services as well as to improve the quality of human resources. United Nation (UN) declared that 17\% tax to GDP ratio is the least level to attain the "Millennium Development Goals" (MDG). On the other side, the OECD countries have increased this ratio to about $35 \%$ of GDP in tax revenues. Usually, the tax to GDP ratio for low income countries is $15-18$ percent. Middle income countries have this ratio of $22-25 \%$ while the high-income countries have $40 \%$ tax to GDP ratio. It is very clear that existing tax to GDP ratio is far lower for Pakistan and it requires to be increased to meet the basic standards of living of people by empowering the tax morale instead of implementing deterrence policies.

If revenues collection of Pakistan is compared with neighboring and other comparable countries (like India, Maldives, Sri Lanka, Bangladesh, Nepal), a

\footnotetext{
${ }^{3}$ For details see, Pakistan Economic Survey (2002-03) to onward.
} 
disappointing situation of the country exists for standing at one of the bottom positions ${ }^{3}$. A comparative picture is presented in the following table (2).

Table: 2 Tax to GDP ratio of Various Countries

\begin{tabular}{lccc}
\hline Country & $\mathbf{2 0 0 5}$ & $\mathbf{2 0 1 0}$ & $\mathbf{2 0 1 5}$ \\
\hline Bangladesh & 8.5 & 9.0 & 9.7 \\
Bhutan & 17.6 & 17.8 & 14.3 \\
India & 15.9 & 16.3 & 17.38 \\
Nepal & 9.2 & 13.4 & 16.5 \\
Sri Lanka & 13.7 & 13.3 & 11.7 \\
European Union & 39.1 & 38.4 & 40.0 \\
\hline
\end{tabular}

Source: World Development Indicators, Economic Survey of Nepal (2014-15), National Revenue Report (Bhutan), Ministry of Finance (Bangladesh).

Fenochietto and Pessino (2013) estimated tax capacity of 113 countries in their study and calculated the ratio between tax capacity and actual tax revenues in these countries. They estimated the tax capacity of Pakistan to be $22.3 \%$ of GDP, which shows a gap of 10\% of GDP as compared to tax revenues collected in 2016.

Tax evasion is usually perceived as uncontrolled in Pakistan. According to some estimates, one in 100 persons in Pakistan pays income tax. Corporate tax evasion is also high, and numbers are stunning: 67,624 companies are enlisted with the Securities Exchange Commission of Pakistan (SECP) in 2015. Less than one third companies submitted filed returns and among those one fifth declared taxable profits. Tax evasion is often emphasized as a pernicious economic problem in Pakistan. The factors explaining such low tax morale in the country remain unknown. Surprisingly, there is hardly any study exploring the determinants of tax morale in Pakistan. Quite clearly, there is a need of empirical investigation explaining the black box of tax morale, as well as, the factors defining the shape and maintenance of tax morale. This study aims to fill this gap by exploring the factors influencing the level of tax morale in Pakistan. After introduction, section 2 outlines the literature review. Section 3 provides the methodology and section 4 presents the estimated results while section 5 has conclusions.

\section{Literature Review}

In literature, there are appealing theories that allow incorporating moral restrictions in a rational model of taxpayers. Strümpel, (1969) investigated tax morale of European people also and performed a survey to examine the tax system

\footnotetext{
${ }^{3}$ For details see The World Bank, http://databank.worldbank.org.
} 
among different European countries and level of tax morale between people of every country's taxpayers. The study found that Germany has comparatively lesser tax morale, while UK has higher. The main disparity between tax systems of UK and Germany was that the German Government used tax enforcement policies, while England regarded tax payers with admirations and lower enforcement. He claimed that the enforcement approaches by German government resulted in pushing the people away and negatively affecting the tax morale. He proposed that the UK system assisted to flourish the tax morale among the people in spite of easy environment to avoid the taxes.

Chung (1976) considered a philanthropic approach that entails tax payers who not only have concern in their personal interest but are also interested in wellbeing of others. The choice to avoid tax is restricted by the level of information that avoidance will decrease the quantity of sources for public benefits. 'Kantian' morality method described another dimension of the theory (Laffont, 1975). This method is generally concerned with Kant's explanation of morale, established on fair tax which any taxpayer considers being good for other tax payers. A wrong assertion will cause to create anxiety and decline in taxpayer's own-worth. It is supposed that a taxpayer will feel harmful impact if he thinks that his tax burden is higher than the others. If he is giving a larger amount of taxes, tax avoidance can be observed as a kind of self-defense.

Alm and Torgler, (2004) studied the tax behavior in United States and 15 other European states applying data sets from "World Values Survey" (WVS), show significance of cultural and social variables. The study showed that United States has top level of tax morale and that certain socio-demographic features matter. Likewise, institutional trust in legal system, parliament and degree of financial satisfaction are also important. They also obtained a negative correlation between the formal sector and the tax morale in the said countries.

Torgler, Schaffner and Macintyre (2008) investigated the factors affecting tax compliance by using multiple regression models to find out the volume of underground economy using tax morale as a dependent variable with per capita GDP, proportion of urban population, proportion of agricultural sector in GDP, marginal tax rate, labor power and regions as independent variables. Their findings show that "substantial growth in the shadow economy can lead to crowding out of willingness to pay taxes". Trade has inverse relation with the volume of underground economy and underground economy has a positive relation with urbanization and share of agricultural sector in GDP. The study found that tax morale has a significant and positive effect on the level of tax compliance. Old 
people and females are more docile and personal wealth negatively affects the level of tax compliance. The analysis of Probit model revealed that institutions, confidence in judiciary, status, educational level, gender and religion are variables that explain the tax morale in a significant manner.

Berenson (2008) evaluated the level of tax compliance for three countries using binomial logit model. The "Tax Compliance Attitudinal Survey" contained questions relevant to theories regarding quasi voluntary tax compliance, deterrence, relation with tax administration and the impacts of the past experiences. The tax compliance is based on the theory of quasi voluntary that rely on confidence in government to offer services and goods and confidence in other people to pay their adequate part of taxes. The comparative analysis highlights the differences in behaviors and attitudes of people in these states. The tax behavior of Russians and Ukrainians is much affected by deterrence policy and highly significant in case of Russia.

Cummings et al. (2009) investigated how the compliance level is affected by tax morale in South Africa, Botswana and other neighboring states having diverse social norms and histories. The findings of the study show that level of tax compliance increases as perceptions of good governance increases. Tax compliance also increases at lower level with perception of less good governance. It is indicated that the concept of good governance is shown by individual responses to apply enforcement regarding penalties and audit to observe a correlation with tax morale. The compliance level is positively affected by enforcement efforts and has a negative correlation with perception of lower level of good governance.

Mughal and Akram (2012) studied 92 cities of Pakistan through conducting a survey and found that all ten of their hypotheses about the tax evasion had a significant impact. These included a lack of tax morale, high taxes, poverty, the proliferation of taxes, inadequate enforcement, the lack of appropriate tax incentives, the lack of a fair and effective tax system, no public lighting campaign, and existence of weak relationship between the tax administration and the taxpayers. They also ranked the hypothesized reasons in descending order of importance. The most common reason is the poor relation between the administration and the taxpayers, followed by lack of appropriate tax incentives, and spread of illiteracy regarding tax collection and then no public lighting campaign. However, if factor loading is considered then ranking is from the nonexistence of public lighting campaign, lack of appropriate tax incentives, the weak relationship between the taxpayers and administration, the proliferation of 
taxes, and finally, illiteracy regarding computation in descending order of importance.

Dorrenberg and Peichl, (2013) investigated the relationship between progressive taxes and tax morale of tax payers. The $4^{\text {th }}$ wave from the World Values Survey (WVS) is used for cross country analysis with tax morale as an endogenous variable, while exogenous and control variables were religiosity, tax progressivity, demographic, trust in government, economic variables and national pride. The results highlighted that married persons and women have higher level of tax morale while religiosity, national pride and employed person have positive relationship with tax morale. The estimated results proved the declining and positive relation between tax morale and progressive taxes and proposed that tax cuts will help to reduce tax evasion. Since the causal relation cannot be deduced. It is quite possible that people having higher tax morale supports a progressive taxes structure.

A huge volume of early tax morale research was performed in mid of previous century by "Cologne school of tax psychology" and the notion of tax morale was ignored at that time by the researchers. Many present-day tax researchers highlighted the significance of tax morale in their research studies but few of them treated it in more detail. A bird's eye view on the literature reveals the importance of tax morale for collection of tax revenues and it appears to be a more effective tool instead of deterrence policy. However, developing economies have very less emphasis on morale aspect of taxation. It can be hypothesized that institutional quality plays an important role to improve the level of tax morale, but this aspect was not considered much for empirical analysis. This study is an attempt to explore the uncovered dimensions of tax morale for Pakistan and findings of study will be helpful to derive policy tools for policy makers to improve the tax revenues of the country.

\section{Methodology}

\subsection{Model}

In order to find out the determinants of tax morale, a model is derived following Allingham and Sandmo (1972). If an individual tax payer $i$ has an income of $Y_{i}$ at each period which is not recognized by tax authorities and the individual taxpayer shows the income $M$ to tax authorities on which a tax $t$ is levied. It is assumed that the individual taxpayer conceals a part ' $v$ ' of his income $Y_{i}$. So;

$M_{i}=\left(1-v_{i}\right) Y_{i}$ 
Assume that $f$ is the penalty must be pay if taxpayer is discovered. Then income will be;

$Y_{a i}=Y_{i}-t\left(1-v_{i}\right) Y-f t v_{i} Y_{i}$

If taxpayer is not discovered, then income will be;

$Y_{b i}=Y_{i}-t\left(1-v_{i}\right) Y i$

Taxpayer can maximize its expected utility by choosing $v$ at each period of time:

$\max E u_{i}\left(Y_{i}\right)=p u_{i}\left(Y_{a i}\right)+(1-p) u_{i}\left(Y_{b i}\right)$

$\mathrm{p}=$ detection probability

Putting the values of $Y_{a i}$ and $Y_{b i}$ in eq (4), we get;

$\max E u_{i}\left(Y_{i}\right)=p u_{i}\left[Y_{i}-t\left(1-v_{i}\right) Y-f t v Y_{i}\right]+(1-p) u_{i}\left[Y_{i}-t\left(1-v_{i}\right) Y_{i}\right]$

According to model of Allingham and Sandmo (1972), the proportion of escaped income is dependent on degree of deterrence policies like fines and detection probabilities.

Fortin et al (2007) included an institutional utility function in individual taxpayers' utility function. So, tax payer's expected utility function will be;

$E U_{i}(Y i)=E u_{i}\left(Y_{i}\right)+Q_{i}\left(v_{i}, Z_{i}\right)$

Where $Q_{i}\left(v_{i}, Z_{i}\right)$ is institutional interaction term representing $v_{i}$ as proportion of evaded income (income which is not recognized by tax authorities) and $Z_{i}$ shows the set of institutional variables associated with tax morale. While; $Q_{i}\left(v_{i}, Z_{i}\right)=q_{i}\left(Z_{i}\right)\left(1-v_{i}\right) Y_{i}$

By substituting the values of $E u_{i}\left(Y_{i}\right)$ and $Q_{i}\left(v_{i}, Z_{i}\right)$ in (6), the expected utility function of tax payers will be as follows;

$$
\begin{gathered}
E U_{i}\left(Y_{i}\right)=p u_{i}\left[Y_{i}-t\left(1-v_{i}\right) Y-f t v Y_{i}\right]+(1-p) u_{i}\left[Y_{i}-t\left(1-v_{i}\right) Y_{i}\right]+[ \\
\left.q_{i}\left(Z_{i}\right)\left(1-v_{i}\right) Y_{i}\right]
\end{gathered}
$$

Upon the basis of above derived expected utility function of tax payers and incorporating the institutional variables, key model for investigating tax morale in Pakistan has following equation;

$T M_{i}=\beta_{0}+\beta_{1} C G_{i}+\beta_{2} C P_{i}+\beta_{3} C C_{i}+\beta 4 R E L_{i}+\beta_{5} C T R_{i}+\varepsilon_{i}$

Where $T M_{i}$ stands for tax morale; $C G_{i}$ is confidence in government; $C P_{i}$ is confidence in parliament; $C C_{i}$ is confidence in civil services; $R E L_{i}$ is religiosity and 
$C T R_{i}$ shows various other variables like age, marital status, gender, financial satisfaction and education.

Weighted ordered probit model is applied for estimation purposes. Usually, a selected sample of data is a miniature of population. It came from which is needed to be reflected for all population measured in a survey. Samples are supported to be adjusted by weighted variables that are used to assess the ranking order of scaled dependent variable like tax morale. It may happen that by combining indicators having high correlation are counted double into an index. A solution has often been given by testing indicators for statistical correlation and choosing only indicators having a low degree of correlation or adjusting weights accordingly, e.g. giving less weight to correlated indicators. Weighted ordered probit model has the capability to assign weights to the estimated variables. During the estimation of these model, the sign of the coefficients is only inferred, not their magnitude. Estimated marginal effects quantify the effect of an explanatory variable on dependent variable. The marginal effect shows changes in behavior of tax payers to a particular level of tax morale, when explanatory variables deviate by single unit.

\subsection{Data and Variables}

Institutions are a set of formal rules and informal norms with their enforcement mechanism structure human interaction. Tax morale is also an institutional and dependent variable explained with rules and norms of the country. The selection of independent variables was carried out by keeping in view the theoretical linkages of previous studies with dependent variable used by Cummings et al. (2009), Fortin et al (2007), Alm and Torgler (2004), Weder (2002), Brock and Durlauf (2001), Allingham and Sandmo (1972) and Strümpel (1969).

To determine tax morale (TM), following question is used by World Value Survey (WVS):

"Please tell me for each of the following actions whether you think it can always be justified, never be justified, or something in between: Cheating on taxes if you have the chance."

Now a description of independent variables used in the model is given. Torgler (2007) proposed that there are many key determinants that appeared to be crucial to understand tax morale. To check the significance of variables to understand tax morale in Pakistan, three variables that strongly suggested these notions were selected from WVS and were used for analysis of tax morale. 
These core variables are explored to find relationship tax payers had with institutions. One of them is Confidence in Government which is computed by the "World Values Survey" as:

"I am going to name a number of organizations. For each one, could you tell me how much confidence you have in them: is it a great deal of confidence, quite a lot of confidence, not very much confidence or none at all? The government (in your nation's capital)"

The other variable employed to investigate the relationship between taxpayers and institutions is "Confidence in the Parliament" which is computed by the "World Values Survey" as:

"I am going to name a number of organizations. For each one, could you tell me how much confidence you have in them: is it a great deal of confidence, quite a lot of confidence, not very much confidence or none at all? Parliament."

The third variable that investigates the relation between taxpayers and authority is "Confidence in the Civil Service" which was computed by "World Values Survey" as:

"I am going to name a number of organizations. For each one, could you tell me how much confidence you have in them: is it a great deal of confidence, quite a lot of confidence, not very much confidence or none at all?: The Civil Service."

These variables helped to determine the confidence on institutions of the country (e.g., confidence in Government), therefore concentrating on how the association between citizens and state is determined, and also permit to examine confidence more adjacent at present politico economic level (For example, Confidence in Parliament and Civil Service).

Religiosity (REL) is a supplementary independent variable which is considered in this study. There are many moral restrictions and norms that are significantly affected by religiosity. Earlier empirical evidences proved that states having higher level of religiosity have substantially lowered violent. Therefore, it might be the situation that religiosity might affect habits of people in terms of white-collar crime.

In order to determine religiosity, the given question is selected from the World Values Survey (WVS):

"Apart from weddings and funerals, about how often do you attend religious services these days?" 
In addition to the above-mentioned variables, other explanatory variables mentioned (i.e. "confidence variables", and "religiosity"), are also utilized as control variables $(C T R)$ like age, gender, marital status, education to investigate the determinants of tax morale.

The data of this study is acquired from the World Values Survey (WVS) ${ }^{4}$ which is an international exploration of social, political, cultural and institutional change. The conducting duration of a survey is called a wave. The waves of survey evaluate prime values and faiths of world. The WVS was started in 1981-84, with succeeding surveys being performed in 1990-94, 1995-98, 1999-2004, 2005-2009 and 2010-2014. The data of these surveys is publicly accessible for use of researchers who are interested to know how beliefs and views altered with the passage of time. The WVS has generated facts of ongoing but persistent modifications which described values, faiths and desires of people. It is suggested that these variations have a vital effect on behavior and social life. This study used the data of sixth wave conducted during 2010-2014.

\section{Estimation}

The estimation is carried out by using weighted ordered probit model. Samples are supported to be adjusted by weighted variables and helpful to assess the ranking order of scaled explained variable like tax morale. During the estimation of weighted ordered probit model, the signs of the coefficients are only inferred, not their magnitude. Estimated marginal effects of weighted ordered probit model quantify the effect of an explanatory variable on dependent variable. The marginal effect shows changes in behavior of tax payers to particular level of tax morale, when explanatory variables deviate by single unit. The estimated weighted ordered probit model explaining the tax morale in Pakistan for WVS 2010-14 is given in Table 3. The estimated results show that confidence in parliament positively and significantly affects the tax morale of the country. It indicates that enhancing one-point confidence in parliament raises the tax morale by 0.82 percentage points.

Confidence in civil service also has a significant positive impact. It is found that by increasing the confidence in civil service by single unit will lead to higher tax morale by 0.42 percentage points. The estimated result declares that confidence in government is also significant at 1 percent on individuals' tax morale and it is estimated that one unit increase in the confidence in government leads to increasing

\footnotetext{
${ }^{4}$ For details of data collection methodology, see http://www.worldvaluessurvey.org/wvs.jsp
} 
the tax morale by 0.91 percentage points. The institutional coefficients (confidence in parliament, confidence in civil service and confidence in government) turned out to be extremely significant. Generally, the findings of the results are robust. Likewise, with the aim to check alternate details, extra variables are included. Religiosity has impact on people's traditions and behavior, and it may be a constraint in the way of tax cheating. Tittle (1980), Grasmick et al. (1991) and Torgler (2002) proved that religiosity alters the intensity of rules violation, tax morale and tax compliance.

\section{Table: 3 Estimated Determinants of Tax Morale}

\begin{tabular}{llll}
\hline D. Variable: Tax Morale & \multicolumn{3}{l}{ Weighted Ordered Probit Model } \\
\hline Variables & Coefficient & Z-stat & Marginal \\
Confidence in Parliament & $0.192^{*}$ & 4.025 & 0.082 \\
Confidence in Civil Service & $0.147^{* *}$ & 3.962 & 0.042 \\
Confidence in Government & $0.186^{*}$ & 3.741 & 0.091 \\
AGE & & & \\
$30-49$ & $0.418^{* *}$ & 3.512 & 0.131 \\
50 and more & 0.325 & 0.639 & 0.071 \\
Marital Status & & & \\
Married & $0.261^{* * *}$ & 3.041 & 0.128 \\
Divorced & 0.419 & 2.258 & 0.051 \\
Separated & 0.417 & 0.729 & 0.062 \\
Widowed & -0.521 & -0.539 & -0.039 \\
Financial Satisfaction & $0.071^{*}$ & 3.830 & 0.062 \\
Religiosity & $0.038^{* *}$ & 2.639 & 0.072 \\
Woman & $0.591^{* *}$ & 2.931 & 0.103 \\
Education & -0.041 & -0.621 & -0.003 \\
No. of Observations = 1200 & & & \\
McFadden's R $=0.86 \quad$ McFadden's Adj R ${ }^{2}=0.83$ & & \\
McKelvey \& Zavoina's R ${ }^{2}=0.92$ & & & \\
AIC $=0.85$ & & & \\
LR = 84.00 & & \\
Prob $>$ LR = 0.00 & &
\end{tabular}

Note: $* * *$ and $* * *$ shows significance at $1 \%, 5 \%$ and $10 \%$ respectively. The reference groups are age up to 29; single; completely satisfied; very important; man and illiterate. Source: Author's own calculations

The findings also supported the above discussed results; religiosity positively affects the tax morale in the country. By adding the income variable for 
analysis in equation, it is analyzed that increasing the level of financial satisfaction by a unit leads to increase the tax morale by 0.62 percentage points.

It can be observed from estimated results that the demographic variable has an influence on the dependent variable. The tested model revealed that demographic variable positively affected the tax morale. The age group from 30 to 49 has positive and significant impact on tax morale as compared with other groups (i.e. the reference group is up to 29 years old). For example, the population having age of 30-49 years have higher level of tax morale contrary to other groups. The estimated results show that tax morale for this group (age 30 - 49) is 0.13 percentage points high as compared with reference age group of up to 29 years. Moreover, it can be seen that marginal effects for tax morale increases as age increases but is not significant for the 50+ age group. It is shown that Pakistani women have higher level of tax moral as compared to men. Married people turn out to have higher tax morale as compared to the singles. Financial satisfaction is also significant at 1 percent to tax morale and shows that one unit increase in financial satisfaction increases the tax morale by 0.62 percentage points. The estimated results are also supported by some other studies carried out for other countries such as Acemoglu et al (2004), Alesina and Perotti (1996), Alm and Torgler (2004), Berenson (2008), Cumming et al (2009), Feld and Frey (2002), Trogler et al (2008). The impact of education is not significant on tax morale in Pakistan. It can be convincingly considered that literate taxpayers are more aware regarding tax laws and taxation networks as compared with uneducated taxpayers, and consequently have more consciousness of advantages and gains the state offered to people. Moreover, literate tax payers might have lower level of cooperation due to better understanding of advantages for avoidance and may be more unfavorable because of awareness of how the state utilize tax revenues. The diagnostic tests reveal the goof fit of the model.

\section{Conclusions and Policy Implications}

This study explored the determinants of tax morale in Pakistan by considering data of World Values Survey (WVS) for the wave of 2010-14. Earlier research studies on this topic have been carried out for Latin America and Europe while no study has been conducted on this subject. Given the extremely low tax to GDP ratio in Pakistan, it is important to analyze the factors that influence tax morale in Pakistan. Previous studies on this topic found a number of important variables to investigate individual's tax morale such as confidence in parliament and confidence in government. People having greater levels of confidence in government or confidence in parliament were also expected to have higher tax morale. Religious 
people have also higher level of tax morale. This study is the first ever empirical investigation on the determinants of tax morale in Pakistan. Resultantly, it advances the reader an understanding into how taxation behavior is evolved in Pakistan for 2010-14.

The foundational intent of this study is to examine the impact of informal and formal institutions influencing the tax morale and to fill this space by considering tax morale as endogenous variable with data set of WVS for Pakistan. Special emphasis has been placed on three institutional elements, which are hardly analyzed in the empirical literature of tax compliance for Pakistan: "confidence in parliament", "confidence in civil service" and "confidence in government". Institutions that enhance the confidence of people will increase tax morale. Furthermore, this study shows that "confidence in parliament", "confidence in civil service" and "confidence in government" have high correlation with higher level of tax morale.

Tax morale is at the heart of state-building and establishes the relationship between citizens and state. This study is an effort to ascertain the determinants and trends that affect the tax morale in the country to identify the following potential areas that may support the efforts of government to improve the tax morale:

- Increasing the confidence of people on institutions and government can enhance the level of tax compliance and tax morale that will lead to raise the revenues.

- Generate profiles of taxpayers: An analysis of the attitudes and perceptions of citizens about tax issues. This will be helpful to provide information about the behaviors of tax payers so government can adopt the effective policy to increase the tax revenues and more resistant groups to pay taxes can be found out. On the other side, volunteer tax payers may have tax benefits and rebates.

- Increase transparency in decisions on financial policy and modernization of tax authorities which will be beneficial to decrease the corruption and will restore the confidence of tax payers. Perceptions about civil services, especially taxes, may affect attitudes toward taxes.

- The simplification of tax system and adoption of modern information technology to raise tax morale and to develop the guide for literacy of tax payers and education.

However, it is notable that this study has some limitations. Firstly, the data of the study gained from the World Values Survey needs to be explored at large extent. Therefore, a survey specifically designed to explore issues related to ethics of taxation may be fruitful in the future. 
The second constraint or it may be considered as a proposal for future investigation is to measure the behavior of tax payers before and after major alterations in tax authorities with different time intervals.

The study employs World Values Survey (WVS) which is based on subjective data measuring the perceptions of people. The answers may not adequately reflect a person's true behavior. People often hide information regarding income and taxation. For example, the tax morale in this study is measured by responses to the following question: "Please tell me for each of the following actions whether you think it can always be justified, never be justified, or something in between: Cheating on taxes if you have the chance." It is quite hard to believe that everyone answered this question accurately.

However, it should be noted that in spite of these restrictions, this study is the first statistical analysis of tax morale in Pakistan and provides an insight to the reader about the attitudes toward taxes in Pakistan. 


\section{References}

Acemoglu, D., Johnson, S., Robinson, J. A. (2004). Institutions as a Fundamental Cause of Long-Run Growth, NBER Working Paper No. 10481

Alesina, A., Perotti, R. (1996). Income Distribution, Political Instability and Investment. European Economic Review, 40(6), 1203-1228.

Allingham, M. G., Sandmo, A. (1972). Income Tax Evasion: A Theoretical Analysis. Journal of Public Economics, 1, 323-338.

Alm, J., Torgler, B. (2004). Culture Differences and Tax Morale in the United States and in Europe. Journal of Economic Psychology, 27(2), 224-246.

Berenson, M. P. (2008). Rationalizing or Empowering Bureaucrats? Tax Administration Reform in Poland and Russia. Journal of Communist Studies \& Transition Politics, 24(1), 136-155.

Brock, W., Durlauf, S. (2001). Discrete Choice with Social Interaction. Review of Economic Studies, 68, 235-260.

Chung, P. (1976). On Complaints about High Taxes, an Analytical Note. Public Finance, 31, 36-47.

Cummings, R. G., Martinez-Vasquez, J., McKee, M., Torgler, B. (2009). Tax Morale Affects Tax Compliance: Evidence from Surveys and an Arte factual Field Experiment. Journal of Economic Behavior and Organization, $70,447-457$.

Dorrenberg, P., Peichl, A. (2013). Progressive Taxation and Tax Morale. Public Choice, 155(3-4), 293-316.

Dubin, J.A. (2007), Criminal Investigation Enforcement Activities and Taxpayer Noncompliance, Public Finance Review, 35: 500-529

Feld, L. P., Frey, B. S. (2002). Trust Breeds Trust: How Taxpayers are Treated. Economics of Governance, 3, 87-99.

Fenochietto, M. R., \& Pessino, M. C. (2013). Understanding countries' tax effort (No. 13-244). International Monetary Fund.

Fortin B., Lacroix G., Villeval M. (2007). Tax Evasion and Social Interactions. Journal of Public Economics, 91, 2089-2112.

Grasmick, H. G., Bursik, R. J., Cochran, J. K. (1991). Render unto Caesar What Is Caesar's: Religiosity and Taxpayers Inclinations to Cheat. Sociological Quarterly, 32, 251-266. 
Hanousek, J., Palda, F. (2004). Quality of Government Services and the Civic Duty to Pay Taxes in the Czech and Slovak Republics and other Transition Countries. Kyklos, 57, 237-52.

Laffont, J. J. (1975). Macroeconomic Constraints, Economic Efficiency and Ethics: an Introduction to Kantian Economics. Economica, 42, 430-437.

Mughal, M. M., Akram M. (2012). Reasons of Tax Avoidance and Tax Evasion: Reflections from Pakistan. Journal of Economics and Behavioral Studies. 4(4), 217-222.

Nelson, R. R., Winter, S. G. (1982). An Evolutionary Theory of Economic Change. Cambridge Massachusetts, The Belknap Press.

Strümpel, B. (1969). Quantitative Analysis in Public Finance, The Contribution of Survey Research to Public Finance in AT Peacock (Ed).

Sugden, R. (1984). Reciprocity: the Supply of Public Goods through Voluntary Contributions. Economic Journal, 94, 772-787.

Tittle, C. (1980). Sanctions and Social Deviance: The Question of Deterrence. Praeger, New York.

Torgler, B. (2002). Preaching Matters: Tax Morale and Religiosity. WWZDiscussion Paper, 02/03, Basel.

Torgler, B. (2007). Tax Morale in Central and Eastern European Countries. In Hayoz, Nicolas \& Hug, Simon (Eds.) Tax Evasion, Trust, and State Capacities. Peter Lang, New York, pp. 155-185.

Torgler, B. and Schneider, F. G. (2007). What Shapes Attitudes toward Paying Taxes? Evidence from Multicultural European Countries. Social Science Quarterly, 88(2), 443-470.

Torgler, B., Schaffner, M., \& Macintyre, A. (2008). Tax Compliance, Tax Morale and Governance Quality. CREMA Working Paper Series 2007-17.

Weder, B. (2002). Model, Myth, or Miracle? Reassessing the Role of Governments in the East Asian Experience. United Nations University Press, New York. 